\title{
Effects of Combined Application of Fertigation and Consortium of Biofertilizers on Biological Properties of Soil Under Banana Cropping System
}

\author{
M. Senthilkumar ${ }^{1}$, P. Paneerselvam ${ }^{2}$, S. Ganesh ${ }^{3}$ and K. Srinivas ${ }^{1}$ \\ ${ }^{1}$ ICAR-Indian Institute of Horticultural Research, Bengaluru-560089, India \\ ${ }^{2}$ ICAR-National Rice Research Institute, Cuttack-753006, India \\ ${ }^{3}$ Gandhigram Rural Institute (Deemed University), Gandhigram-624 302, Tamilnadu, Indoa \\ *Corresponding author
}

\section{A B S T R A C T}

\begin{abstract}
Keywords
Banana,

Biofertilizers, Soil

respiration,

Dehydrogenase

activity, Phospatase

activity

Article Info

Accepted:

08 June 2018

Available Online:

10 July 2018

A field experiment was conducted during 2010-12 in banana cv. Robusta (AAA) to study the effects of combined application of fertigation and consortium of biofertilizers on some of the biological properties of the soil. The results indicated that the application of fertigation with consortium of biofertilizers significantly enhanced the soil respiration (19 to 83 per cent), dehydrogenese activity (52 to 97 per cent), Glomalin content (21 to 72 per cent) and phosphatase activities (Acid phosphatase from 53 to 92 per cent and alkaline phosphatase from 40 to 82 per cent) as compared to only fertigation treatment. In both main and ratoon crops, the fertigation treatment without consortium of biofertilizers recorded the lowest values for these soil biological properties. This study indicated that the soil biological properties can be significantly enhanced by combining fertigation with consortium of biofertilizers which also substantially reduces the requirement of chemical fertilizers up to 25-50 per cent.
\end{abstract}

\section{Introduction}

Banana (Musa sp), is one of the ancient fruits of the world and also an important food for millions of people all around the world. It is the fourth most important commodity (Mustaffa and Kumar, 2012) after rice, wheat and corn. It is grown in more than 130 countries across the world covering an area of 5.0 million ha with a production of 103.63 million tonnes. The fruits are very delicious, nearly fat free, rich in carbohydrate with a

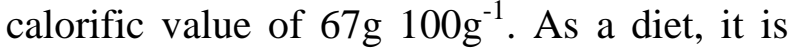
highly satisfying, easily digestible, and suitable to all the age groups and people of all levels.

Banana requires large quantity of mineral nutrients (Senthilkumar et al., 2016) for rapid growth and development thus readily responds to applied nutrients (Mustaffa and Kumar, 2012). For better growth and yield of banana, optimum levels of nutrients have to be maintained which are partly supplied by the 
soil (Swennen, 1990) and the remaining is being supplemented through other alternative sources such as organic manure, inorganic fertilizers and bio-inoculants.

The modern agriculture practices with an aim to obtain higher yield has ended in indiscriminate usage of synthetic fertilizers which resulted in pollution of soil and water besides, reduction in the soil fertility and microbial population. Thus in the recent crop management strategy, biofertilizers have emerged as one of the alternatives to inorganic fertilizers due to various advantages of its application such as increased crop yield by 1530 per cent, replacement of chemical fertilizers by 25 per cent, hastening of flowering and maturity of crops, enhancement of nutrients availability, especially nitrogen and phosphorous and control of soil born diseases.

Microbes are an integral part of soil and contribute to the soil and plant health (Senthilkumar et al., 2016). They have the ability to fix atmospheric nitrogen, solubilize and mobilize phosphorous, produce antibiotics and disease suppressing molecules.

In totality, microbes are considered as biological indicators of soil health as soil health in broad sense is the cumulative effect of the microbial biomass, soil respiration, enzyme activities and microbial diversity (Brussaard et al., 2007).

Worldwide, fertigation is widely adopted in banana cropping system as it reduces the nutrient requirement of the plants considerably due to higher nutrient use efficiency. If fertigation is combined with biofertilizers there is a possibility of further reduction in the input requirement. Inclusion of biofertilizers will help beneficial microbes to proliferate, provide residual effects for subsequent crops besides recycling and decomposition of organic matter. Further, they improve plant growth by releasing vitamins auxins and hormones, aprt from improving the physical, chemical and biological properties of soil (Senthilkumar et al., 2016).

Under this backdrop, there is a need to thoroughly investigate the influence of biofertilizers in enhancing the soil biological properties when biofertilizers is applied along with fertigation as it will help in further refinement of the production technology of Banana so as to improve the production and productivity without any adverse effects on the soil health.

Therefore an experiment was carried out to study the effects of combined application of fertigation and consortium of biofertilizers in enhancing the soil biological properties under banana based cropping system.

\section{Materials and Methods}

The present study was conducted during 20102012 at the ICAR-Indian Institute of Horticultural Research (IIHR), Hesarghatta, Bengaluru which is situated at $13^{0} 58^{\prime}$ North latitude and $78^{\circ}$ East longitude with an altitude of 890 meters. Sword suckers of cultivar Robusta (AAA) with uniform size weighing around $0.80-1.00 \mathrm{~kg}$ were used for planting.

The $100 \%$ recommended dose of fertilizer used for banana crop was $200 \mathrm{~g} \mathrm{~N}, 110 \mathrm{~g}$ P and $200 \mathrm{~g} \mathrm{~K} \mathrm{plant}^{-1}$ crop cycle $^{-1}$ (Anon, 2006).

The entire quantity of phosphorous as single super phosphate (16 per cent P) was applied (Senthilkumar et al., 2016) in the pit before planting and after fifteen days, the consortium of biofertilizers comprised of Azospirillum and phosphate solubilizing bacterial strain (Bacillus aryabhattai), and Arbuscular Mychorrizhal (AM) fungi in equal proportions was incorporated. 
The fertigation was started at $60^{\text {th }}$ day of planting and continued up to 320 days at weekly interval (Senthilkumar et al., 2013). Nitrogen as Calcium Ammonium Nitrate (25 per cent $\mathrm{N}$ and 15 per cent $\mathrm{Ca}$ ) and potassium as Muriate of Potash (60 per cent K) were flushed into drip irrigation system through fertilizer injector.

The experiment was laid out in a Randomised block design with three replications and twelve treatments viz., $\mathrm{T}_{1^{-}}$Farmyard manure $+300 \mathrm{~g}$ of Consortium of biofertilizers (CBF), $\mathrm{T}_{2}-100 \%$ Recommended dose of Fertilizer through fertigation (RDFTF) $+100 \mathrm{~g}$ of $\mathrm{CBF}, \mathrm{T}_{3}-100 \% \mathrm{RDFTF}+200 \mathrm{~g}$ of $\mathrm{CBF}, \mathrm{T}_{4}-$ $100 \%$ RDFTF $+300 \mathrm{~g}$ of $\mathrm{CBF}, \mathrm{T}_{5}-75 \%$ $\mathrm{RDFTF}+100 \mathrm{~g}$ of $\mathrm{CBF}, \mathrm{T}_{6}-75 \% \mathrm{RDFTF}+$ $200 \mathrm{~g}$ of $\mathrm{CBF}, \mathrm{T}_{7}-75 \% \mathrm{RDFTF}+300 \mathrm{~g}$ of $\mathrm{CBF}, \mathrm{T}_{8}-50 \% \mathrm{RDFTF}+100 \mathrm{~g}$ of $\mathrm{CBF}, \mathrm{T}_{9}-50 \%$ $\mathrm{RDFTF}+200 \mathrm{~g}$ of CBF, ${ }_{10}-50 \%$ RDFTF + $300 \mathrm{~g}$ of CBF, $\mathrm{T}_{11}-100 \% \mathrm{RDFTF}, \mathrm{T}_{12}-100 \%$

Recommended dose of fertilizer through soil (RDFTS)-Control. Irrigation was scheduled on a daily basis to replenish 80 per cent of the evaporation losses (Senthilkumar et al., 2016). Three uniformly grown plants were selected for observation in each treatment.

The rhizosphere soil samples and plant roots of banana at $15-30 \mathrm{~cm}$ depth which were collected at 180 days after planting and at harvest were used for estimation of soil respiration. For estimating Dehydrogenase activity, glomalin content and the phosphatise activities, the rhizosphere soil samples collected at harvest were used.

\section{Assay of soil dehydrogenase activity in soil}

Dehydrogenase activity (DHA) was determined following the method of Casida et al., (1964) was expressed as $\mu \mathrm{g}$ TPF $\mathrm{g}^{-1}$ dry soil $\mathrm{h}^{-1}$.

\section{Soil respiration}

The soil respiration was carried as per the procedure suggested by Isermayer (1952).

\section{Phosphatase activity in soil}

The estimation of Acid and Alkaline phsophatase was carried out in triplicate as per the protocol elucidated by Eivazi and Tabatabai (1977).

\section{Estimation of Glomalin}

The glomalin content of the soil samples was analyzed using the Bradford protein assay as modified by Wright and Upadhyaya (1996).

The data were analyzed using Web Agri. Stat Package version WASP 1.0 developed by the ICAR- Central Coastal Agricultural Research Institute, Goa and subjected to one way analysis of variance (ANOVA). Treatment difference was evaluated using least significant difference (LSD) at $\mathrm{p} \geq 0.05$.

\section{Results and Discussion}

\section{Soil respiration}

Application of consortium of biofertilizers significantly influenced the soil respiration at different growth stages. Soil respiration was higher at 180 days after planting and there was a gradual decline in the soil respiration in the main crop at harvest indicating the reduction in the microbial population and necessity of applying the biofertilizers for the next crop. Consequent to the application of consortium of biofertilizers the soil respiration again increased in the ratoon crop and gradually decreased at harvest.

Critical observation revealed that the soil respiration was higher at reduced fertigation levels with higher doses of consortium of 
biofertilizers. The fertilizer dose of $75 \%$ through fertigation with consortium of biofertilizers consistently resulted in higher soil respiration. Especially, $75 \%$ recommended dose of fertilizer through fertigation with $300 \mathrm{~g}$ of consortium of biofertilizers recorded significantly higher respiration rate in both main and ratoon crops with a value of 9.10 and $10.03 \mathrm{mg} \mathrm{kg}^{-1}$ soil $\mathrm{hr}^{-}$ ${ }^{1}$ respectively.

This indicated that the microbial population will not adversely be affected at reduced rates of fertilizer dose. It also indicated that higher doses of inorganic fertilizers, though economical in terms of yield, they are not very conducive for better microbial growth and their beneficial activities in the rhizosphere soil (Senthilkumar et al., 2016). Further, the soil respiration at $100 \%$ recommended dose of fertilizers applied through soil and $100 \%$ recommended dose of fertilizers through fertigation (both were without consortium of biofertilizers) recorded less soil respiration as compared to inoculated treatments. The $100 \%$ recommended dose of fertilizer applied through soil recorded the lowest rate of soil respiration with a value of 5.19 and $5.22 \mathrm{mg}$ $\mathrm{kg}^{-1}$ soil $\mathrm{hr}^{-1}$ respectively at harvest. This might be due to the fact that only inorganic fertilizers application was not conducive for the growth of native microbes in the rhizosphere of banana which resulted in low soil respiration.

\section{Deydrogenase activity}

Soil enzymes play an important role in various biochemical functions in the soil such as organic matter decomposition, catalyzing several reactions which are necessary for the life processes of microorganisms in soil, stabilization of soil structure, decomposition of organic wastes, organic matter formation, and nutrient cycling (Ebersberger et al., 2003). Particularly, dehydrogenase activity is an indication of the activeness of the microbial population in the rhizosphere soil. The soil samples of different treatments, analyzed at harvest of the main crop significantly differed in the dehydrogenase activity. In general, the treatments with the combination of consortium of biofertilizers resulted in significantly higher dehydrogenase activity than the un-inoculated treatments. At harvest of the main crop, the dehydrogenase activity was higher at the lower doses of fertigation with higher levels of consortium of biofertilizers. This was evident from the fact that dehydrogenase activity recorded at $100 \%$ recommended dose of fertilizers with the combination of consortium of biofertilizers was less than the $50 \%$ recommended dose of fertilizers through fertigation with the combination of consortium of biofertilizers. Similar trend was noticed in the ratoon crop also

Among the treatments, the highest values (85.80 and $88.8 \mu \mathrm{g}$ TPF $\mathrm{g}^{-1}$ soil $\mathrm{hr}^{-1}$ ) were recorded at $75 \%$ recommended dose of fertilizer through fertigation with $300 \mathrm{~g}$ of consortium of biofertilizers which was significantly higher than the $100 \%$ recommended dose of fertilizer through soil application (48.4 and $51.8 \mu \mathrm{g} \mathrm{TPF} \mathrm{g}^{-1}$ soil $\mathrm{hr}^{-1}$ ) and the treatment with $100 \%$ recommended dose of fertilizer through fertigation (42.80 and $45.8 \mu \mathrm{g} \mathrm{TPF} \mathrm{g}^{-1}$ soil $\mathrm{hr}^{-1}$ ).

The pooled data at harvest, indicated that dehydrogenase activity ranged from $44.30 \mu \mathrm{g}$ TPF $\mathrm{g}^{-1}$ soil hr ${ }^{-1}$ (100\% recommended dose of fertilizer through fertigation) to $87.30 \mu \mathrm{g}$ TPF $\mathrm{g}^{-1}$ soil $\mathrm{hr}^{-1}$ (75\% recommended dose of fertilizer through fertigation with $300 \mathrm{~g}$ of consortium of biofertilizers).

\section{Glomalin production}

Soil aggregation is a complex process which is mainly dependent upon secretion of microbial polysaccharides or gummy substances that hold soil particles together. Among the many soil microbes, Arbuscular Mycorrhizal (AM) 
fungi are considered to be primary soil aggregators. Recent evidence suggests that glomalin a glycoprotein is known to be secreted only by AM fungi in the taxon Glomales, including fungi of the genera Acaulospora, Entrophospora, Gigaspora, Glomus, and Scutellospora which have a cementing capacity to maintain soil particles together (Singh, 2012). Thus, the AM fungi enhances the water holding capacity of the soil there by improve the plant water relations, potentially contributing to increased crop drought resistance (Auge, 2003) which can cut short total water requirement of banana as it is a water and nutrient exhaustive crop considerably. AM Fungi and their product glomalin affect the carbon (C) dynamics in agro ecosystems (Singh, 16) apart from their key role in the soil aggregation.

The rhizosphere soil samples collected from all the treatments were analysed for total glomalin. Though the initial soil samples analyzed did not show any marked difference in the glomalin content among the treatments, the soil samples collected at harvest shown significant difference among the treatments. It was significantly highest at the treatments applied with consortium of biofertilizers as compared to un-inoculated control in both the cropping season.

The treatment of $75 \%$ recommended dose of fertilizer through fertigation with consortium of biofertilizers recorded 63 and 81 per cent higher glomalin content as compared to the treatment with $100 \%$ recommended dose of fertilizers through fertigation. The pooled data of two years also revealed higher glomalin content (71 per cent) compared to the un inoculated fertigation treatment. Similarly, Panneerselvam et al., (2012) reported that application of AM fungi along with Pseudomonas putida increased total glomalin content by 40 per cent compared to the uninoculated control, whereas G. mosseae alone increased it by 22 per cent.

\section{Phosphatase activities}

Phosphorus is an essential nutrient for plant growth and crop yield, however a large portion is immobilized because of intrinsic characteristics of soils such as $\mathrm{pH}$ that affects the availability of nutrients and the activity of enzymes, altering the equilibrium of the soil solid phase (Dick et al., 2000). Soil microorganisms play a key role on phosphate solubilisation with the release of low molecular weight organic acids (Sundara et al.,2002) and production of extracellular enzymes as phosphatases. Phosphatases are a group of enzymes that catalyze hydrolysis of esters and anhydrides of phosphoric acid. Its activity depends on extracellular enzymes, which can be free in the soil water phase or stabilized in the humic fraction or clay soil content (Sundara et al., 2002). In soil, phosphomonoesterases have been the most studied enzymes probably because they have activity both under acidic and alkaline conditions, according to its optimal $\mathrm{pH}$, and because they act on low molecular Pcompounds including nucleotides, sugar phosphates and polyphosphates (Makoi and Ndakidemi, 2008); thus they can be used as soil quality indicators as the acid and alkaline phosphate of the rhizosphere soil is directly proportional to the microbial population.

In this study the acid and alkaline phosphatase activity was higher at $75 \%$ recommended dose of fertilizer through fertigation with consortium of biofertilizers followed by $50 \%$ recommended dose of fertilizers through fertigation with consortium of biofertilizers. Comparatively, the $100 \%$ recommended dose of fertilizers through fertigation with consortium of biofertilizers resulted in lower acid and alkaline phosphatase activity indicating the inhibitory effect of higher doses of inorganic fertilizer on the microbial growth in the rhizosphere soil (Table 1-3). 
Table.1 Effect of fertigation and consortium of biofertilizers on soil respiration $\left(\mathrm{mg} \mathrm{kg}^{-1}\right.$ soil $\left.\mathrm{hr}^{-1}\right)$

\begin{tabular}{|c|c|c|c|c|c|c|c|}
\hline \multirow[t]{2}{*}{ Treatments } & \multirow[b]{2}{*}{ Initial } & \multicolumn{2}{|c|}{ Main crop } & \multicolumn{2}{|c|}{ Ratoon crop } & \multicolumn{2}{|c|}{ Pooled } \\
\hline & & 180 DAP & At harvest & 180 DAP & At harvest & 180 DAP & At harvest \\
\hline 1. FYM\&300 g CBF & 5.30 & 6.84 & 6.15 & 7.69 & 6.27 & 7.26 & 6.21 \\
\hline 2. $100 \%$ RDFTF\&100 g CBF & 5.32 & 7.54 & 6.48 & 7.82 & 6.53 & 7.68 & 6.51 \\
\hline 3. $100 \%$ RDFTF \& 200 g CBF & 6.13 & 9.13 & 7.61 & 10.13 & 8.23 & 9.63 & 7.92 \\
\hline 4. $100 \%$ RDFTF \& 300 g CBF & 5.41 & 7.93 & 6.74 & 8.26 & 6.67 & 8.10 & 6.71 \\
\hline $5.75 \%$ RDFTF\&100 g CBF & 6.28 & 8.98 & 7.94 & 9.72 & 8.09 & 9.35 & 8.02 \\
\hline 6. $75 \%$ RDFTF\& 200 g CBF & 5.31 & 9.78 & 8.73 & 10.01 & 8.89 & 9.90 & 8.81 \\
\hline 7. $75 \%$ RDFTF \& 300 g CBF & 5.63 & 10.31 & 9.10 & 11.33 & 10.03 & 10.82 & 9.56 \\
\hline 8. 50\% RDFTF \& 100 g CBF & 6.01 & 7.10 & 6.19 & 7.36 & 6.69 & 7.23 & 6.44 \\
\hline 9. 50\% RDFTF\& 200 g CBF & 5.58 & 7.43 & 6.26 & 7.63 & 6.73 & 7.53 & 6.49 \\
\hline 10. 50\% RDFTF\& $300 \mathrm{~g} \mathrm{CBF}$ & 5.49 & 8.16 & 6.86 & 8.29 & 7.13 & 8.23 & 7.00 \\
\hline $11.100 \%$ RDFTF & 5.39 & 5.89 & 5.07 & 6.13 & 5.38 & 6.01 & 5.22 \\
\hline 12. $100 \%$ RDFTS & 5.28 & 6.03 & 5.19 & 6.26 & 5.22 & 6.15 & 5.20 \\
\hline S.Em \pm & - & 0.41 & 0.35 & 0.44 & 0.38 & 0.43 & 0.37 \\
\hline C.D at $5 \%$ & NS & 1.20 & 1.04 & 1.30 & 1.11 & 1.25 & 1.07 \\
\hline
\end{tabular}

FYM- Farmyard manure, RDFTF- Recommended dose of fertilizers through fertigation, RDFTS- Recommended dose of fertilizers through soil, CBFConsortium of biofertilizers. 
Table.2 Effect of fertigation and consortium of biofertilizers on Dehydrogenase activity and glomalin production at harvest

\begin{tabular}{|c|c|c|c|c|c|c|c|c|}
\hline \multirow[t]{2}{*}{ Treatments } & \multicolumn{4}{|c|}{ Dehydrogenase activity $\left(\mu \mathrm{g}\right.$ TPF $\mathrm{g}^{-1}$ soil $^{-1}$ ) } & \multicolumn{4}{|c|}{ Glomalin production $\left(\mathrm{mg} \mathrm{g}^{-1}\right.$ soil $)$} \\
\hline & Initial & $\begin{array}{l}\text { Main } \\
\text { crop }\end{array}$ & $\begin{array}{c}\text { Ratoon } \\
\text { crop }\end{array}$ & Pooled & Initial & $\begin{array}{c}\text { Main } \\
\text { crop }\end{array}$ & Ratoon crop & Pooled \\
\hline 1. FYM\&300 g CBF & 29.80 & 68.90 & 71.30 & 70.10 & 3.38 & 5.78 & 5.83 & 5.81 \\
\hline 2. $100 \%$ RDFTF \&100 g CBF & 31.40 & 67.50 & 66.85 & 67.18 & 3.76 & 5.21 & 5.68 & 5.45 \\
\hline 3. $100 \%$ RDFTF\& $200 \mathrm{~g} \mathrm{CBF}$ & 30.70 & 72.30 & 74.70 & 73.50 & 3.33 & 6.48 & 6.92 & 6.70 \\
\hline 4. $100 \%$ RDFTF\& $300 \mathrm{~g}$ CBF & 28.80 & 69.80 & 70.50 & 70.15 & 4.01 & 6.08 & 6.78 & 6.43 \\
\hline $5.75 \%$ RDFTF\& $100 \mathrm{~g} \mathrm{CBF}$ & 29.50 & 81.70 & 82.60 & 82.15 & 3.33 & 6.39 & 7.09 & 6.74 \\
\hline 6. $75 \%$ RDFTF\& $200 \mathrm{~g} \mathrm{CBF}$ & 31.30 & 84.20 & 84.60 & 84.40 & 3.67 & 6.89 & 7.38 & 7.14 \\
\hline 7. $75 \%$ RDFTF\& $300 \mathrm{~g} \mathrm{CBF}$ & 30.03 & 85.80 & 88.80 & 87.30 & 4.03 & 7.66 & 7.82 & 7.74 \\
\hline 8. 50\% RDFTF\& $100 \mathrm{~g} \mathrm{CBF}$ & 27.81 & 70.20 & 71.60 & 70.90 & 3.43 & 6.09 & 6.52 & 6.31 \\
\hline 9. 50\% RDFTF\& $200 \mathrm{~g}$ CBF & 32.24 & 73.40 & 74.86 & 74.13 & 3.39 & 6.27 & 6.77 & 6.52 \\
\hline $10.50 \%$ RDFTF\& $300 \mathrm{~g} \mathrm{CBF}$ & 33.10 & 76.70 & 79.30 & 78.00 & 3.44 & 6.83 & 7.23 & 7.03 \\
\hline 11. 100\% RDFTF & 29.40 & 42.80 & 45.80 & 44.30 & 3.59 & 4.68 & 4.34 & 4.51 \\
\hline 12. $100 \%$ RDFTS & 30.33 & 48.40 & 51.80 & 50.10 & 3.69 & 4.73 & 4.31 & 4.52 \\
\hline S.Em \pm & - & 3.48 & 3.59 & 3.54 & - & 0.31 & 0.32 & 0.31 \\
\hline C.D at $5 \%$ & NS & 10.21 & 10.55 & 10.38 & NS & 0.90 & 0.93 & 0.92 \\
\hline
\end{tabular}


Table.3 Effect of fertigation and consortium of biofertilizers on phosphomonoesterase activity in soil

\begin{tabular}{|c|c|c|c|c|c|c|c|c|}
\hline \multirow[t]{2}{*}{ Treatments } & \multicolumn{4}{|c|}{ Acid Phosphatase activity ( $\mu \mathrm{g} \mathrm{PNP} \mathrm{g}^{-1}$ soil $\mathrm{hr}^{-1}$ ) } & \multicolumn{4}{|c|}{ Alkaline phosphatase activity $\left(\mu \mathrm{g} \mathrm{PNP}^{-1}\right.$ soil hr } \\
\hline & Initial & Main crop & Ratoon crop & Pooled & Initial & Main crop & Ratoon crop & Pooled \\
\hline 1. FYM\&300 g CBF & 36.61 & 68.90 & 70.90 & 69.90 & 5.30 & 75.80 & 84.30 & 80.05 \\
\hline 2. $100 \%$ RDFTF\&100 g CBF & 35.53 & 66.70 & 68.03 & 67.37 & 5.32 & 73.30 & 79.50 & 76.40 \\
\hline 3. $100 \%$ RDFTF\& 200 g CBF & 37.45 & 69.30 & 71.17 & 70.24 & 6.13 & 79.40 & 82.80 & 81.10 \\
\hline 4. $100 \%$ RDFTF \& $300 \mathrm{~g} \mathrm{CBF}$ & 35.78 & 67.40 & 69.43 & 68.42 & 5.41 & 78.10 & 81.90 & 80.00 \\
\hline $5.75 \%$ RDFTF\& 100 g CBF & 37.13 & 78.60 & 81.31 & 79.96 & 6.28 & 95.10 & 96.75 & 95.93 \\
\hline 6. $75 \%$ RDFTF\& $200 \mathrm{~g}$ CBF & 36.86 & 82.30 & 85.10 & 83.70 & 5.31 & 96.20 & 102.90 & 99.55 \\
\hline 7. $75 \%$ RDFTF\& $300 \mathrm{~g} \mathrm{CBF}$ & 37.21 & 83.90 & 85.31 & 84.61 & 5.63 & 87.96 & 99.80 & 93.88 \\
\hline 8. 50\% RDFTF\& $100 \mathrm{~g}$ CBF & 36.66 & 72.70 & 74.50 & 73.60 & 6.01 & 87.20 & 87.60 & 87.40 \\
\hline 9. 50\% RDFTF\& $200 \mathrm{~g}$ CBF & 35.99 & 73.90 & 74.70 & 74.30 & 5.58 & 87.90 & 88.90 & 88.40 \\
\hline $10.50 \%$ RDFTF \& $300 \mathrm{~g}$ CBF & 38.48 & 76.60 & 78.30 & 77.45 & 5.49 & 91.10 & 93.70 & 92.40 \\
\hline $11.100 \%$ RDFTF & 35.01 & 43.90 & 44.20 & 44.05 & 5.39 & 53.20 & 56.30 & 54.75 \\
\hline 12. $100 \%$ RDFTS & 36.16 & 53.80 & 54.90 & 54.35 & 5.28 & 60.70 & 69.60 & 65.15 \\
\hline S.Em \pm & - & 3.45 & 3.53 & 3.49 & - & 3.85 & 4.18 & 4.01 \\
\hline C.D at $5 \%$ & NS & 10.12 & 10.35 & 10.24 & NS & 11.28 & 12.27 & 11.77 \\
\hline
\end{tabular}

FYM- Farmyard manure, RDFTF- Recommended dose of fertilizers through fertigation, RDFTS- Recommended dose of fertilizers through soil, CBFConsortium of biofertilizers. 
This could be reconfirmed by the lowest acid and alkaline phosphatase activity recorded at $100 \%$ recommended dose of fertilizers through fertigation without consortium of biofertilizers.

Phosphatase activity in rhizosphere soil is related to AM fungal activity of plants (Chethan Kumar et a1., 2008). AM fungal colonization is known to alter the inherent phosphorus supply by increasing phosphatase activity in the plant rhizosphere (Allen et al., 1995) and in confirmation Sumana (1998) reported an increase in acid phosphatase activity with increased colonization by AM fungi. Thus, it could be inferred that the application of consortium of biofertilizers which had AM fungi as one of the components could have resulted in significantly higher acid and alkaline phosphatase activity in all the inoculated treatments as compared to un-inoculated control.

Phosphatases secreted in hyphae catalyse the hydrolysis of both organic $\mathrm{P}$ esters and anhydrate of phosphoric acid into inorganic $\mathrm{P}$. Higher activities of acid and alkaline phosphatase in the rhizosphere soil of banana are indicative of better phosphorus utilization by plants inoculated with consortium of biofertilizers with AM fungi. Earlier investigation by Lynch et al., (1991) revealed a positive relationship between $\mathrm{P}$ absorption and plant growth as they reported a strong connection between $\mathrm{P}$ absorption activity and dry matter production.

Hence concluded in this study the combined application of fertigation with consortium of biofertilizer resulted in higher rate of soil respiration, dehydrogenic and phospatase activities which is an indication of the presence of higher population of microbes in the rhizosphere soil which are considered as biological indicators of soil health. It was noted that the lesser levels of fertigation and higher levels of consortium of biofertilizers resulted in more soil respiration, dehydrogenic and phospatase activities. Among the treatments $75 \%$ recommended dose of fertilizers through fertigation combined with the consortium of fertilizers found to be the ideal combination followed by $50 \%$ recommended dose of fertilizers through fertigation with the consortium of fertilizers in up-keeping the soil health in a long run.

\section{References}

Allen, E.B., Allen, M.F., Helm, D.J., Trappe, J.M., Moliva, R. and Rincon, E. 1995. Patterns and regulation of mycorrhizal and fungal diversity. Plant and Soil, 170: 47-62.

Augé, R.M., Moore, J.L., Cho, K., Stutz, J.C., Sylvia, D.M., Al-Agely, A.K. and Saxton, A.M. 2003. Relating foliar dehydration tolerance of mycorrhizal Phaseolus vulgaris to soil and root colonization by hyphae. J. plant physiology. 31; 160(10):1147-56.

Brussaard, L., De Ruiter, P.C. and Brown, G.G. 2007. Soil biodiversity for agricultural sustainability. Agriculture Ecosystems and Environment, 121, 233-244.

Casida, L.E., Klein, D. and Santoro, T. 1964. Soil dehydrogenase activity. Soil Sci., 98: 371-376.

Chethan Kumar, K.V., Chandrashekar, K.R. and Lakshimipathy, R. 2008. Variation in arbuscular mycorrhizal fungi and phosphatase activity associated with Sida caldifolia in Karnataka. World J. Agric Sci., 4:770774.

Dick, W.A., Cheng. L. and Wang, P. 2000. Soil acid and alkaline phosphatase activity as $\mathrm{pH}$ adjustment indicators. Soil Biology and Biochemistry. 32(13):1915. 
Ebersberger, D., Niklaus, P.A., Kandeler, E. 2003. Long term CO 2 enrichment stimulates $\mathrm{N}$-mineralisation and enzyme activities in calcareous grassland. Soil Biology and Biochemistry. 35(7):965-72.

Eivazi. F. and Tabatabai, M.A. 1977. Phosphatase in soils. Soil Biology and Biochemistry, 9: 167-172.

Isermayer, H.1952. Eine einpache method zur bestimmung der pflanzenatmung under carbonate in boden, ZPflanzenernahr. Dung, Bodenk.56:26-28

Lynch, J., Lauchli, A. and Epstein, E. 1991. Vegetative growth of the common bean in response to $\mathrm{P}$ nutrition. Crop Sci., 31:380-387.

Makoi, J.H. and Ndakidemi, P.A.2008. Selected soil enzymes: examples of their potential roles in the ecosystem. African J. Biotechnology. 5;7(3).

Mustaffa, M.M. and Kumar, V. 2012. Banana production and productivity enhancement through spatial, water and nutrient management. J. Hort. Sci., 7(1):1-28.

Panneerselvam.P., Boya Saritha, Sukhada Mohandas, Kaushal Kishore Upreti, Poovarasan, Ajay Monnappa and Vijay Virupakshayya Sulladmath 2012. Glomus mossae associated bacteria and their influence on stimulation of mycorrhizal colonization, sporulation and growth promotion in guava (Psidium gujava L.) seedlings. Biological Agri. and Hort., 28(4): 267-279.

Senthilkumar,M., Ganesh,S., Srinivas,K. and
Paneerselvam, P.2013. Enhancing growth and yield in banana cv.Robusta(AAA) through fertigation with microbial consortium, J.Horti.Sci., 8(2):240-245.

Senthilkumar, M., Ganesh, S., Srinivas,K., Paneerselvam, P. and Kasinath, B.L.2016. Combining fertigation and consortium of bio-fertilizers for enhancing growth and yield of banana cv. Robusta(AAA), Indian J.Hort., 73(1):36-41.

Singh, P.K. 2012. Role of Glomalin Related Soil Protein Produced by Arbuscular Mycorrhizal Fungi: A Review. Agric. Sci. Res. J., 2(3), 119-125,

Sumana, D.A.1998. Influence of VA mycorrhizal fungi and nitrogen fixing and mycorrhization helper bacteria on growth of neem (Azardirachta indica A. Juss) PhD thesis, University of Agricultural Sciences, Bangalore.

Sundara, B., Natarajan, V. and Hari, K. 2002. Influence of phosphorus solubilizing bacteria on the changes in soil available phosphorus and sugarcane and sugar yields. Field Crops Res., 77(1):43-9.

Swennen, R.1990. Plantain cultivation under West African conditions. A reference manual. International Institute of Tropical Agriculture, Ibadan, Nigeria. 24-26

Wright, S.F. and Upadhyaya, A. 1996. Extraction of an abundant and unusual protein from soil and comparison with hyphal protein of arbuscular mycorrhizal fungi. Soil Sci., 161:575586.

\section{How to cite this article:}

Senthilkumar, M., P. Paneerselvam, S. Ganesh and Srinivas, K. 2018. Effects of Combined Application of Fertigation and Consortium of Biofertilizers on Biological Properties of Soil Under Banana Cropping System. Int.J.Curr.Microbiol.App.Sci. 7(07): 833-842. doi: https://doi.org/10.20546/ijcmas.2018.707.102 